\title{
PROSTOROVÉ REGRESNÍ MODELOVÁNÍ S PŘÍKLADY
}

\author{
Jiří HORÁK ${ }^{1}$, Lucie ORLÍKOVÁ ${ }^{1}$, Joaquín Osorio ARJONA², Radek SVOBODA ${ }^{3}$ \\ ${ }^{1}$ Katedra geoinformatiky, Hornicko-geologická fakulta, Vysoká škola báňská - Technická univerzita Ostrava, \\ 17. listopadu 2172/15, 70800 Ostrava, Česká republika \\ jiri.horak@vsb.cz, lucie.orlikova@vsb.cz \\ ${ }^{2}$ Universidad Complutense de Madrid, Department of Geography, Madrid, Španělsko \\ joaquoso@ucm.es \\ ${ }^{3}$ Katedra informatiky, Fakulta elektrotechniky a informatiky, Vysoká škola báňská - Technická univerzita \\ Ostrava, 17. listopadu 2172/15, 70800 Ostrava, Česká republika \\ radek.svoboda@vsb.cz \\ doi: https://doi.org/10.31490/9788024843988-10
}

\begin{abstract}
Abstrakt
Prostorové regresní modelování představuje jednu z možností jak využít prostorových vazeb ve vícerozměrné statistice a rozšiření klasických regresních modelů. Cílem příspěvku je představit využití prostorového regresního modelování na 2 př́ikladech. Analýza nezaměstnanosti v Česku byla provedena s využitím vybraných faktorů na základě testování prostorového autoregresního modelování a geografické vážené regrese. Druhý príklad je zaměřena na vyhodnocení tweetů $k$ dopravě ve Španělsku $s$ využitím geografické vážené regrese.
\end{abstract}

\section{Abstract}

Spatial regression modelling with examples: Spatial regression modelling represents one of the popular possibilities how to integrate spatial relationships into multidimensional statistics and to an extension of the classic linear regression models. The aim of the paper is to demonstrate the utilization of spatial regression modelling in two case studies. The unemployment analysis in the Czech Republic employed spatial autoregressive models and a geographical weighted regression. The second case study is focused on evaluation of the spatial distribution of Spain tweets commenting public transport using a geographical weighted regression.

\section{Klíčová slova: prostorová regrese; SAR; geografická vážená regrese; nezaměstnanost; veřejná doprava; Twitter}

Keywords: spatial regression; SAR; Geographically Weighted Regression; unemployment; public transport; Twitter

\section{1. ÚVOD}

Prostorové regresní modelování představuje slibné rozšiření klasických regresních modelů $\mathrm{s}$ využitím prostorové struktury dat. Snaží se tím adresovat jeden z hlavních nedostatků klasických regresních modelů pracujících s prostorovými daty, tedy jejich nedostatek nezávislosti mezi pozorováními v blízkých místech, což způsobuje porušení jednoho ze základních principů řešení regresních rovnic.

Současná nabídka programových implementací prostorového regresního modelování je poměrně široká a stále více uživatelů ji využívá pro své analýzy. Ne všichni si ale uvědomují vhodnost některých postupů a jejich výsledky tím mohou být nepř́ijemně poznamenány.

Cílem tohoto příspěvku je poskytnout jistý návod a doporučení, jak $\mathrm{k}$ těmto analýzám prìstupovat, jaký by měl být postup a na co si dávat pozor. Domnívám se, že takový text v současnosti chybí. Na druhou stranu omezený rozsah příspěvku ve sborníku nedává dostatečný prostor na podrobnější popis a zejména dostatek ukázek.

Některé postupy jsou demonstrovány na 2 případových studiích: míra nezaměstnanosti $v$ ČR a distribuce tweetů k dopravě metrem v metropolitní oblasti Madridu.

\section{STRUČNÝ PŘEHLED PROSTOROVÝCH REGRESNÍCH MODELŮ}

Pro teoretické základy Ize odkázat na Anselin (1988, 2002), LeSage (1998), Haining (2003), Elhorst (2010), Smith et al. (2018), Ivan (2014), Horák (2019). 
Základní otázky jsou, jak vyjádřit prostorovou závislost a jak ji efektivně integrovat do regresních rovnic.

Lze rozlišit dva rozdílné přístupy:

- prostorová závislost je řešena na globální úrovni $s$ využitím explicitní podoby prostorové autokorelace (modely autoregresního typu jako je SAR či MRSA)

- prostorová závislost je řešena na lokální úrovni prostřednictvím lokálně proměnných parametrů modelu (např. GWR).

SAR (spatial autoregressive model) představuje v čisté podobě model, který používá k výpočtu cílové proměnné y pouze její hodnoty $v$ sousedství.

$$
\mathbf{y}=\rho \mathbf{W y}+\boldsymbol{\varepsilon}
$$

Autoregresní parametr $\rho$ vyjadřuje prostorovou závislost a odhaduje se $z$ dat $s$ využitím zpravidla raádkové standardizace matice prostorových vah W (Smith et al, 2018); $\varepsilon$ je chybový vektor.

Model $v$ čisté podobě nevyuživá žádné nezávisle proměnné, proto se často o ně rozšiřuje a dostáváme smíšený regresně-prostorový autoregresní model (mixed regressive spatial autoregressive model mrsa). Patři k nim i jednoduché modely implementované v programu GeoDa, tj. spatial lag model SLM a spatial error model SEM.

Model prostorového kroku SLM specifikuje prostorovou závislost pouze pro cílovou proměnnou a ne pro nezávisle proměnné:

\section{$y=X \beta+\rho W y+\varepsilon$}

$\mathrm{s}$ vektorem nezávisle proměnných $\mathrm{X}$ a jejich regresními koeficienty $\beta$, prostorovým autoregresním parametrem $\boldsymbol{\rho}$, maticí vah $\mathbf{W}$ a chybovým vektorem $\boldsymbol{\varepsilon}$.

Autokorelační chybový model SEM naopak vyjadřuje prostorovou závislost přes autokorelaci reziduí („chyb“) v modelu (Anselin, 2002):

\section{$\boldsymbol{y}=\boldsymbol{X} \boldsymbol{\beta}+\boldsymbol{\varepsilon} \quad k d e \boldsymbol{\varepsilon}=\lambda \boldsymbol{W} \boldsymbol{\varepsilon}+\boldsymbol{u}$}

kde $\lambda$ je koeficient prostorové korelace chyb modelu, $\varepsilon$ je vektor prostorově autokorelovaných chyb a u je vektor chyb.

Při optimalizaci se pak hledá, který z modelů SLM a SEM je v dané situaci kvalitnější. Uvádí se, že SLM se prosazuje tam, kde je menší vliv neznámých proměnných, zatímco pokud poskytuje lepší výsledky SEM, ukazuje to na významný vliv neznámých proměnných.

Podstatné je, že u autoregresních modelů se získává 1 typ vztahu (rovnice) platná pro celé území, tedy prostorové koeficienty $\rho$ či lambda vyjadřuji jistou průměrnou prostorovou závislost $v$ celém území.

Odlišný př́istup je použit u geograficky vážené regrese (GWR), kde se vztahy mezi proměnnými (rovnice) v území mění (Brunsdon et al., 1996). Metoda GWR tedy předpokládá možnost existence prostorových odlišností ve vztazích dvou a více proměnných a poskytuje způsob, jak tyto odchylky měřit.

Základem je vztah (Smith et al., 2018):

$$
\mathbf{y}=\mathbf{X B}(\mathrm{t})+\boldsymbol{\varepsilon}
$$

Regresní koeficienty $\beta(\mathrm{t})$ jsou určovány ze sady bodů $v$ definovaném okolí každého měřeného místa. Okolí je většinou kruhové s poloměrem $r$ (anizotropní modely nejsou v současnosti podporovány). Namísto konstantní hodnoty $r$ se použivá vzdálenostní funkce vedoucí ke kernelovým odhadům

Dosah okolí se optimalizuje pomocí Akaike informačního kritéria (AIC) nebo kř́žovou validací. To však někdy selhává - u malého rozsahu to může skončit zahrnutím celého území nebo optimalizace v programovém prostředí (např. v ArcGIS) vůbec nelze řešit.

Výsledné odhady lokálních regresních parametrů se vizualizují a hodnotí z hlediska prostorové změny vztahu.

Při použití GWR tak můžeme získat jiný funkční vztah mezi dvěma proměnnými v závislosti na charakteru určitého regionu atd. Napríklad vztah mezi cenou bytu a hustotou zalidnění v jeho okolí může být prostorově velmi odlišný, nebot' na cenu bytu má vliv množství dalších charakteristik, které uvedený vztah modifikují (Spurná 2008).

Doporučuje se provádět současně modelování oběma způsoby (autoregresní i lokálně regresní modely), protože každý z nich sleduje jiné vlivy a má jinou interpretaci (Horák, Orlíková 2019). 


\section{POSTUP PŘÍPRAVY MODELU}

Na začátku př́pravy každého regresního modelu je potřebné si dobře rozmyslet, co je závisle proměnná $Y$, jaké jsou nezávisle proměnné $X_{1}$ až $X_{n}$, resp. vysvětlující proměnné.

To nemusí být tak jednoduché, jak vypadá, viz další text k provedení EDA, kdy se zvažuje, které proměnné a v jaké podobě se použijí v regresním vztahu.

Klíčové je také rozhodnutí, jaký typ modelu připravujeme. Zjednodušeně Ize říci, že rozlišujeme:

- Exploratorní (vysvětlující) s pevně danými proměnnými, u nichž nás zajímají jejich vztahy a vliv na Y

- Prediktivní (předpovědní) kde je cílem je co nejlépe vypočítat (odhadnout) Y ze sady proměnných.

$\mathrm{Na} z a c ̌ a ́ t k u$ každého modelování se používá průzkumová analýza dat (Exploratory Data Analysis EDA), jejímž cílem je poznat vlastnosti datových sad. U prostorových dat se pak více mluví o ESDA (Exploratory Spatial Data Analysis), která zkoumá i prostorové vlastnosti dat.

EDA zahrnuje analýzu distribuce každé proměnné, zejména ocenění její asymetrie a provedení vzájemné korelační a regresní analýzy všech proměnných. Cílem EDA je odhalit problémy proměnných $s$ heteroskedascitou a odstranit multikolinearitu vznikající díky úzkým korelacím nezávisle proměnných.

Je vhodné také počítat sekundární proměnné, jako jsou poměry (míry, kvocienty, indexy) a kvưli problému MAUP (Openshaw, 1984) také hustoty (přepočty na plochu).

Pro odstranění asymetrie je zejména u predikčních modelů potřebné provést vhodnou transformaci, která zlepší symetrii distribuce proměnné, jinak mohou být vychýlené výsledné odhady závisle proměnné. U vysvětlujících modelů se ale po transformaci můžeme potýkat s vhodnou interpretací, protože daleko snáze se interpretuji původní veličiny (zejména s využitím jejich standardizovaných regresních koeficientů).

Pro predikční modely, zejména u proměnných s velmi odlišnými rozsahy hodnot, je zpravidla potřebné provést standardizaci proměnných, nejběžnější je Z-standardizace. Opět platí, že standardizace v prípadě vysvětlujicích modelů, může komplikovat interpretaci vlivu jednotlivých nezávisle proměnných.

Z hlediska ESDA je třeba správně volit typ prostorového sousedství a parametry (typy sousedství viz např. Horák, 2019). Je nutné zvažovat, jaký princip sousedství je v dané prostorové situaci vhodný a jaké bude mít volba důsledky. Nelze spoléhat slepě na optimalizační postupy. Je potřebné kontrolovat počty sousedů a všímat si zvláštních situací (Praha, okrajová místa apod.). Jednoduché kontroly nabízí např. GeoDa (viz obr. 1, kdy po nastavení sousedství na Euklidovskou vzdálenost $15 \mathrm{~km}$ se zjišt'uje, které obce budou ovlivněny malým počtem dat a kolik jich bude).

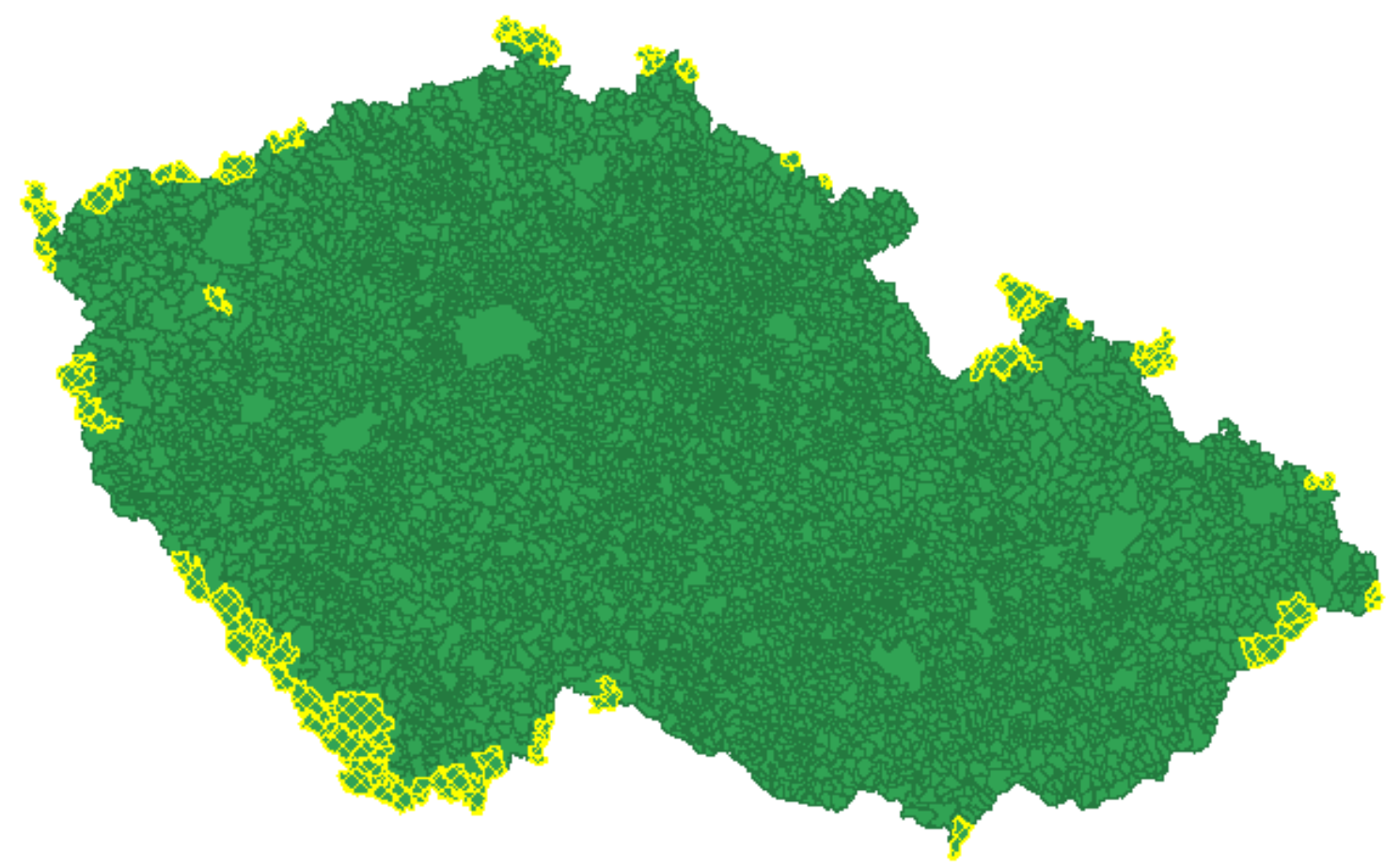

Obr. 1 Obce ČR s méně než 15 sousedy do vzdálenosti 15 km v programu GeoDa

\section{OLS}


Na začátku prostorového regresního modelování se provádí standardní mnohonásobné lineární regresní modelování optimalizované zpravidla metodou nejmenších čtverců, proto se používá zkratka OLS (Ordinary Least Squarre). OLS umožňuje získat představu o celkovém (globálním) chování proměnných v regresní rovnici. Představuje i určitý benchmark, protože s jeho statistickými výsledky (oceňujícími kvalitu modelu) se porovnávají výsledky prostorového regresního modelování a pochopitelně se předpokládá, že prostorový regresní model je musí výrazně zlepšit, jinak Ize těžko prokázat přidanou hodnotu prostorového regresního modelu.

Předpoklady dat pro mnohonásobnou lineární regresní analýzu (upraveno podle Vaus, 2002, Rabušic et al., 2019):

1. Závisle proměnná $Y$ musí být metrická proměnná (numerická v kontinuální škále, alespoň intervalová data), jinak se musí provést logistická regrese.

2. Nezávisle proměnné mají být rovněž stejného typu, ale př́ípustná jsou i dichotomická (binární) data. U ostatních proměnných používáme umělé (dummy) proměnné.

3. Nezávisle proměnné nemají být mezi sebou vysoce korelované, aby nebyla v modelu multikolinearita

4. V datech nemají být odlehlé hodnoty, protože na ty je regresní analýza citlivá

5. Proměnné musejí být v lineárním vztahu, protože na tom je mnohonásobná lineární regresní analýza založena.

6. Vztahy mezi proměnnými nevykazují heteroskedascitu, tj. rozptyl veličiny se nemění v závislosti na hodnotě.

7. Počet záznamů (počet případů) musí být dostatečně velký vzhledem k počtu nezávisle proměnných. Doporučuje se 20 či alespoň 15 na každou nezávisle proměnnou. Uplatnění pravidla však není slepé. Pokud máte sice malý počet záznamů, ale každý reprezentuje agregaci např. z mnoha set či tisíc individuální prípadů), je to vyhovující.

Vztahy zejména mezi nezávisle proměnnými se prověřuji korelační a regresní analýzou, v jejímž rámci se samozřejmě používají i neparametrické korelační koeficienty (např. Spearman, Kendal Tau) pro zachycení nelineárních vazeb. Kvưli multikolinearitě se doporučuje elimininovat proměnné s korelačním koeficientem vůči jiné nezávisle proměnné vyšším než 0.8 (Smith et al., 2018, Rabušic et al., 2019).

Pro posouzení významu jednotlivých proměnných v regresní rovnici a eliminaci pŕípadné multikolinearity se zpravidla používá Variance Inflation Factor (VIF). VIF jedné proměnné by měl být obecně nižší než 5 (Akinwande et al. 2015, Rabušic et al., 2019), existují ale i jiné názory na tuto hranici (např. 8). Vedle VIF se používá i tolerance, která má být menší než 0.2 (Rabušic et al., 2019).

Pro podrobnější vysvětlení mnohonásobné lineární regrese a přiklady doporučuji knihu Rabušic et al. (2019). Citlivou otázkou je vypuštění odlehlých hodnot, tedy anomálií z modelu. Odlehlé hodnoty samožrejmě negativně ovlivňují nejen statistickou kvalitu modelu, ale mohou i pokřivit charakteristiku reálných vztahů popsaných $v$ regresních rovnicích. Bohužel není jednoznačné doporučení, zda (a jaké) odlehlé hodnoty $z$ modelu odstranit či ne. Obecně platí, že je to více vhodné u prediktivních modelů než u exploratorních. Pochopitelně u velkých objemů dat je vyloučení několika hodnot méně citlivé než u malého souboru dat.

\subsection{KVALITA MODELU OLS}

$K$ hodnocení kvality celého modelu se používá několik charakteristik a testů.

$\mathrm{Na}$ 1.místě se zpravidla uvádí koeficient determinace $R^{2}$. Je vhodné používat jeho adjustovanou variantu, zejména pro menší datové soubory (adjustovaný $R^{2}$ totiž přepočte $R^{2}$ na rozsah vzorku, což ukáže jeho reálnou sílu). Někdy tento přepočet může vést až $k$ záporné hodnotě $R^{2}$, což samozřejmě neprospěje důvěře $v$ kvalitu modelu. $R^{2}$ (adjustované) má být pochopitelně co největší, někteří autoři uvádějí, že alespoň 0.5 je potřebných pro kvalitní model. Prírozeně platí, že čím menší datový soubor a čím více nezávisle proměnných, tím snadněji získáte vysoké $\mathrm{R}^{2}$. Proto zejména u malých datových souborů nespoléhejte pouze na $R^{2}$.

AIC (pozor na rozdíly v hodnotách AIC a AICc) by mělo být co nejmenší. CN (condition number) má být nízké, někteří autoři uvádějí do 30.

Testy heteroskedascity (Breusch-Pagan, Koenker-Bassett) mají potvrdit neexistenci heteroskedascity $v$ datech.

Testy normality reziduí (Kolmogorov-Smirnov, Shapiro-Wilk, Jarque-Bera) mají potvrdit normalitu reziduí modelu. Jarque-Bera test se jeví jako jednodušší a snad i lépe splnitelný. Počíá se jednoduše z poměru mezi šikmostí a špičatostí distribuce (je využit např. v ArcGIS). Špatný výsledek jednoho z pokusných GWR 
modelů pro madridská data je uveden na obr. 2 (histogram) a 3 (testy normality). Je třeba říci, že na rozdíl od dř́vějších názorů se $v$ současnosti normalita reziduí u velkých souborů nepovažuje za vážný problém, protože vzhledem $\mathrm{k}$ citlivosti testů stačí několik výchylek, aby test neprošel. $V$ případě pochybností je vhodné prozkoumat distribuci reziduí a nespoléhat pouze na výsledek testu.

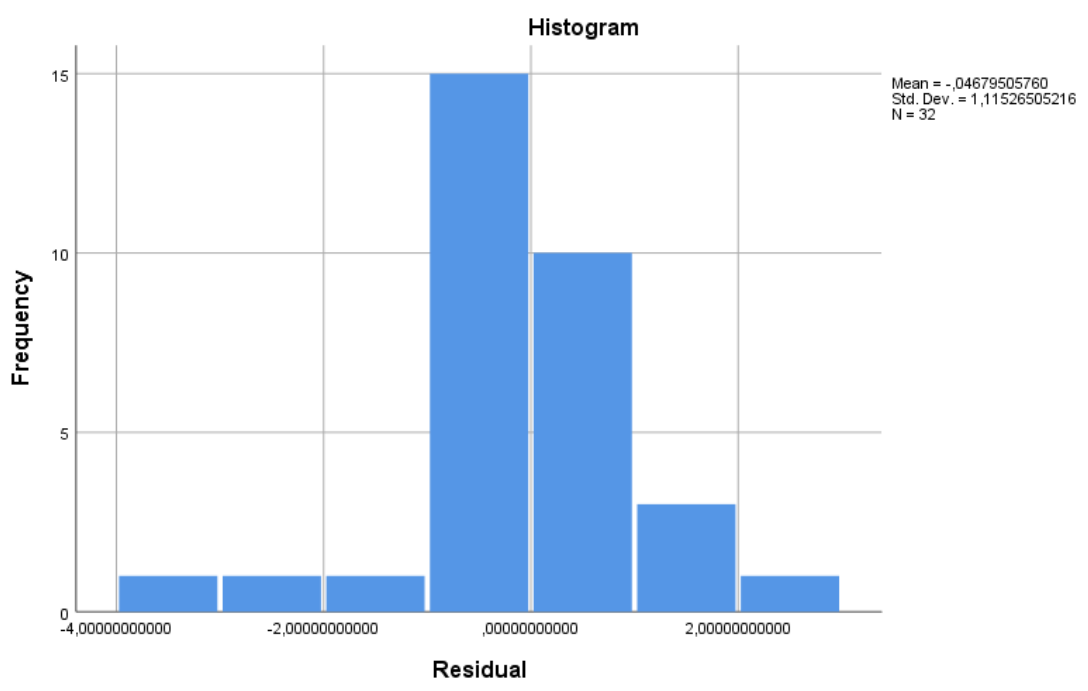

Obr. 2 Histogram vychýlených reziduí jednoho s pokusných GWR modelů v Madridu

\begin{tabular}{|c|c|c|c|c|c|c|}
\hline \multicolumn{7}{|c|}{ Tests of Normality } \\
\hline & \multicolumn{3}{|c|}{ Kolmogorov-Smirnov ${ }^{3}$} & \multicolumn{3}{|c|}{ Shapiro-Wilk } \\
\hline & Statistic & df & Sig. & Statistic & df & Sig. \\
\hline Residual & ,237 & 32 &, 000 & ,831 & 32 &, 000 \\
\hline
\end{tabular}

\section{a. Lilliefors Significance Correction}

Obr. 3 Nesplněné výsledky testů normality reziduí jednoho s pokusných GWR modelů v Madridu

Významnost modelu se posuzuje pomocí F-testu pro ANOVA.

Testuje se rovněž prostorová autokorelace reziduí, k čemuž se často používá pouze jednoduchý výpočet Moranova I kritéria pro celou datovou sadu. Zatímco OLS model je v př́ípadě vysoké prostorové autokorelace reziduí špatný, je tato situace pro prostorové regresní modelování naopak výhodná, protože Ize očekávat, že právě toto modelování problém odstraní a prostorovou autokorelaci naopak využije k podstatnému vylepšení modelu. Všimněme si, že třeba $v$ ArcGIS průzkumném regresním modelování se jako výchozí hodnota pro výběr vhodného prostorového regresního modelu používá hodnota Moranova I > 0.5 . Rovněž významnost prostorové autokorelace by měla být ověřena (např. permutacemi v prostředí GeoDa). Zatímco u OLS modelu často zjistíme významnou prostorovou autokorelaci reziduí, u výsledků prostorových modelů by měly být rezidua prostorově nekorelovaná (obr. 4).

Ve výsledném modelu se hodnotí také velikost absolutního členu v regresní rovnici (interecept) (konstanta $v$ OLS či SAR). Pokud je príliš velký ve vztahu $k$ hodnotám členů v rovnici, ukazuje to spíše na malou vysvětlující sílu modelu. Takový model pak může být jen matematickým řešením konkrétní úlohy, ale nepřispěje reálně $k$ pochopení vazeb. Projevuje se to zejména u proměnných $s$ asymetrickou distribucí $a$ nelineárních vztahů.

ArcGIS nabízí exploratorní regresní modelování, které ze zadaného širokého seznamu nezávisle proměnných kombinatorickým způsobem hledá zajímavé regresní modely, které splňují nastavená kritéria kvality modelu. Příklad takového výstupu je zkráceně dokumentován v př́loze 1.

Dobrý regresní model OLS je dokumentován v př́loze 2 (výsledky z programu GeoDa) nebo v př́loze 3 (výsledek jiného modelu v ArcGIS). 
Pro interpretaci výsledků OLS modelu je vhodné také vypočítat standardizované beta koeficienty (viz https://www.statisticshowto.datasciencecentral.com/standardized-beta-coefficient/).

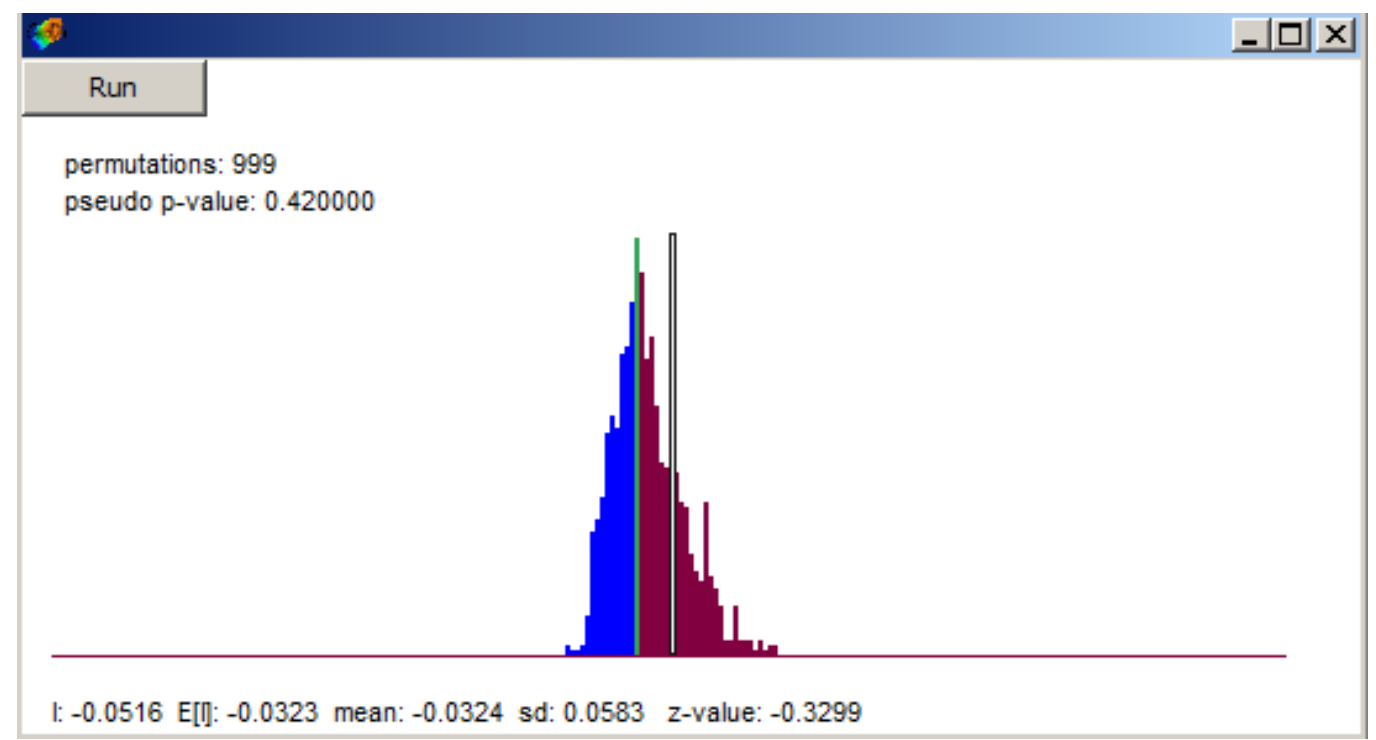

Obr. 4 Negativní prověření významnosti prostorové autokorelace reziduí modelu permutacemi v prostředí GeoDa (GWR model g2dens)

\section{PŘíPADOVÁ STUDIE MÍRY NEZAMĚSTNANOSTI V OBCÍCH ČESKA}

Studie byla publikována v Horák, Orlíková (2019), zde jsou uvedeny jen vybrané části.

Cílem studie bylo posoudit významnost vlivu prostorového faktoru v regresním modelu nezaměstnanosti. Analýza byla provedena pro obce, protože se předpokládaly lepší prostorové vazby (vyšší prostorová autokorelace) i při vědomí komplikace ve značných rozdílech ve velikosti a tvaru obcí. Posuzovala se situace v březnu 2011 kvůli časovému souladu s daty SLDB 2011.

Cílovou proměnnou byla míra nezaměstnanosti, nezávisle proměnné se vybíraly z následujícího seznamu:

- Podíl populace ve věku 65+ (Age6500)

- podíl obyvatel se základním vzděláním a nižším (EduLow)

- podíl obyvatel s vysokoškolským vzděláním (EduUniv)

- Podíl věrících (Relig)

- Podíl cizinců (FOREIGN)

- Podilů rodáků (osoby narozené ve stejné obci) (NATIVE)

- Podíl dvou a více hospodařících domácností v 1 bytové domácnosti (TooHousH),

- Podíl obydlených bytů $v$ bytových domech se sníženou kvalitou (PoorFlat),

- podíl hospodařících domácností v bytech s 5 a více členy domácnost (LargeFam),

- Podíl osob vyjíždějících do práce (Commute),

- Podíl osob denně vyjíždějících do práce (commuteD),

- Podíl zaměstnaných osob z 1000 obyvatel (EMPLO)

- Podíl volných míst na 1000 obyvatel (VACANT)

Po provedení EDA a ESDA se připravoval OLS model. Během vývoje byly vypuštěny proměnné TOOHOUSH $(p=0.167)$ a COMMUTEND $(p=0.143)$. Výsledné $R^{2}$ dosáhlo pouze 0.22 . Vliv nezávisle proměnných odpovídal očekávání (obr. 5). Model však nebyl uspokojivý - hlavní problémem byla globální multikolinearita $(\mathrm{CN}=35)$, distribuce reziduí nebyla normální a existovala vysoká prostorová autokorelace reziduí. 


\begin{tabular}{cccccccc}
\hline Variables & Coefficient & StdError & t-stat & $\mathrm{p}$ & Robust_t & Robust_P & VIF \\
\hline Intercept & 13.058520 & 0.669 & 19.53 & $0.000^{\star}$ & 15.1 & $0.000^{\star}$ & --- \\
AGE6500 & -0.215940 & 0.016 & -13.32 & $0.000^{\star}$ & -9.9 & $0.000^{\star}$ & 1.27 \\
EDULOW & 0.328725 & 0.016 & 20.20 & $0.000^{\star}$ & 13.6 & $0.000^{\star}$ & 1.69 \\
EDUUNIV & -0.152825 & 0.025 & -6.18 & $0.000^{\star}$ & -5.5 & $0.000^{\star}$ & 1.69 \\
RELIG & 0.057473 & 0.007 & 7.89 & $0.000^{\star}$ & 6.9 & $0.000^{\star}$ & 2.18 \\
FOREIGN & -0.107717 & 0.054 & -1.98 & $0.048 *$ & -2.7 & $0.006^{\star}$ & 1.04 \\
NATIVE & -0.099488 & 0.009 & -10.68 & $0.000^{\star}$ & -8.6 & $0.000^{\star}$ & 2.11 \\
POORFLAT & 0.234455 & 0.019 & 12.04 & $0.000^{\star}$ & 8.7 & $0.000^{\star}$ & 1.10 \\
LARGEFAM & 0.106314 & 0.019 & 5.58 & $0.000^{\star}$ & 4.2 & $0.000^{\star}$ & 1.42 \\
COMMUTED & -0.042991 & 0.005 & -8.43 & $0.000^{\star}$ & -7.1 & $0.000^{\star}$ & 1.39 \\
EMPLO & -0.001496 & 0.000 & -5.87 & $0.000^{\star}$ & -3.5 & $0.000^{\star}$ & 1.21 \\
VACANT & -0.019269 & 0.008 & -2.35 & $0.019 *$ & -2.3 & $0.018 *$ & 1.13 \\
\hline
\end{tabular}

Obr. 5 Seznam členů mnohonásobného lineárního regresního modelu vč. nestandardizovaných koeficientů (Horák, Orlíková, 2019)

Následně byl vyvíjen prostorový autoregresní model. Byly porovnány modely SLM a SEM a vybrán SEM podle vyšších hodnot Lagrangeova multiplikátoru a Robust LM.

SEM model má $R^{2}=0.40$ a rovněž AIC je lepší než u OLS modelu. Výsledky modelu jsou uvedeny na obr. 6 . Je zřejmá významná role prostorového autokorelačního faktoru $\lambda$.

\begin{tabular}{ccccc}
\hline Variables & Coefficient & Std.Error & z-value & Probability \\
\hline CONSTANT & 13.964 & 0.7925 & 17.61931 & 0.00000 \\
AGE6500 & -0.128 & 0.0157 & -8.178051 & 0.00000 \\
EDULOW & 0.207 & 0.0154 & 13.4538 & 0.00000 \\
EDUUNIV & -0.120 & 0.0238 & -5.051099 & 0.00000 \\
RELIG & -0.030 & 0.0088 & -3.42988 & 0.00060 \\
NATIVE & -0.097 & 0.0087 & -11.14488 & 0.00000 \\
POORFLAT & 0.229 & 0.0176 & 12.99703 & 0.00000 \\
LARGEFAM & 0.088 & 0.0171 & 5.155249 & 0.00000 \\
EMPLO & -0.0014 & 0.0002 & -6.751055 & 0.00000 \\
LAMBDA & 0.8969 & 0.0156 & 57.60186 & 0.00000 \\
\hline
\end{tabular}

Obr. 6 Výsledky Spatial Error Modelu pro míru nezaměstnanosti v obcích ČR 3/2011 (Horák, Orlíková, 2019)

Nakonec byl vytvořen rovněž geografický vážený model GWR. Šířka pásma byla optimalizována podle AIC a adjusted $R^{2}$ na $15 \mathrm{~km}$. Výsledný model je sice uspokojivý, přesto má nadále problémy s vysokou lokální multikolinearitou (vysoké $\mathrm{CN}$, i když ESDA neukázala žádný problém) a podle očekávání distribuce rezudií není $\mathrm{N}$ (což je ale vzhledem k velikosti vzorku pochopitelné). Výsledná tabulka na obr. 7 ukazuje rozsah hodnot jednotlivých proměnných regresních koeficientủ a podíly zastoupení kladných a záporných hodnot. 


\begin{tabular}{cccccc}
\hline Variables & min & median & max & \% of negative & \% of positive \\
\hline Intercept & -16.32 & 14.16 & 44.89 & 2.38 & 97.62 \\
AGE6500 & -0.84 & -0.10 & 0.83 & 74.07 & 25.93 \\
EDULOW & -0.43 & 0.2 & 1.34 & 9.16 & 90.84 \\
EDUUNIV & -1.41 & -0.16 & 1.10 & 74.00 & 26.00 \\
RELIG & -0.91 & -0.02 & 0.93 & 55.44 & 44.56 \\
FOREIGN & -3.72 & 0.00 & 6.52 & 49.88 & 50.12 \\
NATIVE & -0.44 & -0.11 & 0.19 & 89.23 & 10.77 \\
POORFLAT & -0.46 & 0.19 & 1.15 & 8.49 & 91.51 \\
LARGEFAM & -0.58 & 0.06 & 1.13 & 33.92 & 66.08 \\
COMMUTED & -0.44 & -0.01 & 0.21 & 60.20 & 39.80 \\
EMPLO & -0.04 & -0.002 & 0.02 & 89.34 & 10.66 \\
VACANT & -0.67 & -0.002 & 1.34 & 50.92 & 49.08 \\
\hline
\end{tabular}

Obr. 7 Výsledky GWR pro míru nezaměstnanosti v obcích ČR 3/2011 (Horák, Orlíková, 2019)

Pro ilustraci výsledků jsou uvedeny ještě 2 obrázky. První z nich (obr. 8) ukazuje hodnoty regresního koeficientu pro nezávisle proměnnou „podíl osob s nízkým vzděláním“, který ukazuje prakticky jednoznačně pozitivní vliv na míru nezaměstnanosti, avšak s rozdílnou silou tohoto vztahu. Vedle toho podíl osob s vysokoškolským vzděláním (obr. 9) vykazuje bipolární vliv, tj. jak očekávaný převládající negativní vliv na MN, tak i místa s pozitivním vlivem na MN (resp. kde převládají jiné faktory).

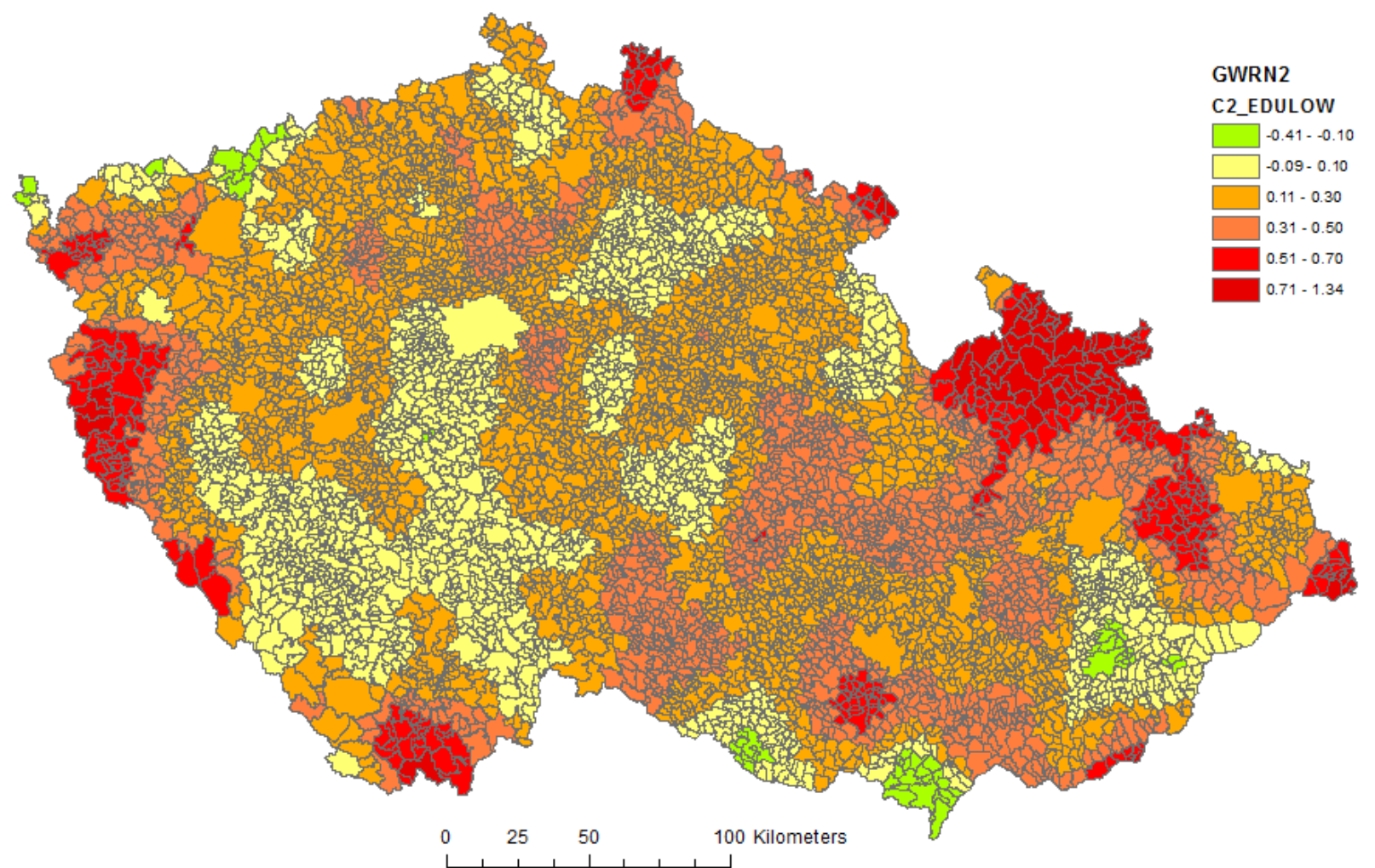

Obr. 8 Lokální regresní koeficienty vliv podílu osob s nízkým vzděláním na míru nezaměstnanosti v obcích ČR, 3/2011 (Horák, Orlíková, 2019) 


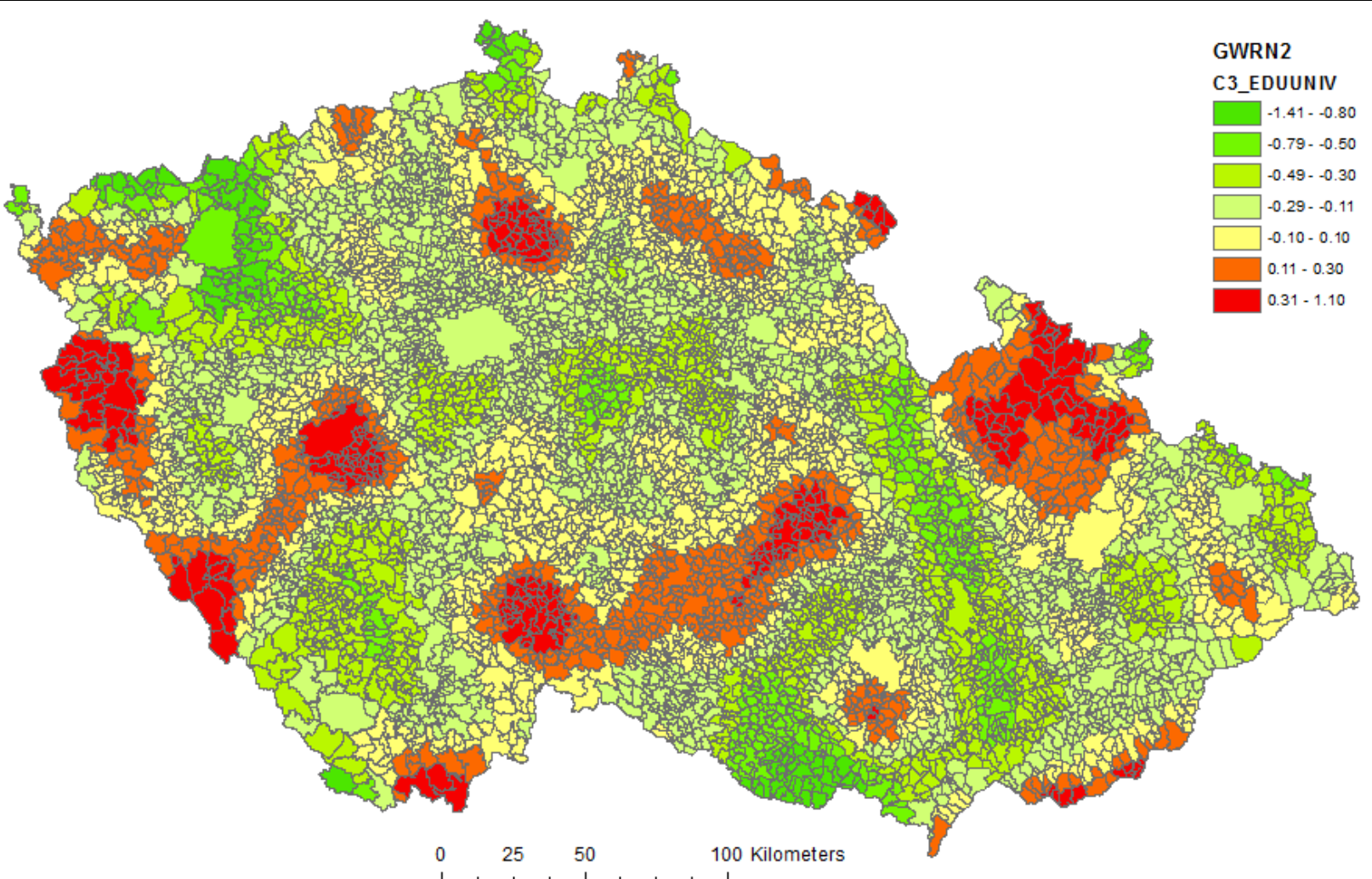

Obr. 9 Lokální regresní koeficienty vlivu podílu osob s vysokoškolským vzděláním na míru nezaměstnanosti v obcích ČR, 3/2011

\section{PŘíPADOVÁ STUDIE DISTRIBUCE PŘíSPĚVKŮ $V$ SÍTI TWITTER K DOPRAVĚ METREM V MADRIDU}

Vzhledem k tomu, že publikace hlavních výsledků regresního modelování teprve probíhá, omezíme se zde jen na základní informace a dokumentaci problémů, se kterými je možné se setkat při vývoji vhodného modelu.

Cílem studie bylo posoudit distribuci názorů lidí na veřejnou dopravu v Madridu a posoudit jejich přičiny. Komplikací při prostorovém hodnocení je zejména fakt, že tweety obsahují souřadnice pouze asi u $1 \%$ př́ípadů.

Pro potřeby analýzy byl použit dvouměsiční vzorek tweetů na oficiálním účtu metra. Ke stahování bylo využito Twitter API s vyloučením retweetů. Následovalo zpracování textu tweetů, jejich čištění (např. převod na malá písmena, transformace španělských znaků $s$ diakritikou, odstranění speciálních znaků), geokódování a nakonec sémantická analýza a analýza sentimentu.

Při sémantické analýze se nejdřive zkoušela práce se slovníky a kombinacemi slov, která však dosáhla pouze cca $50 \%$ přesnosti. Následně byl použit jiný prístup, využívající shlukování textu pomocí Latent Dirichlet Allocation. Tato metoda dokázala odlišit 5 shluků, z nichž 4 poskytly vhodnou interpretovatelnost. Jednotlivé shluky tak reprezentují stižnosti osob na přesnost, komfort, poruchy a přeplnění dopravy. Celkově se podařilo dosáhnout cca $70 \%$ přesnosti.

Při analýze sentimentu bylo přiděleno pozitivní nebo negativní skóre každému tweetu. Byl využit BERT model hlubokého učení (Devlin, Chang, Lee, \& Toutanova, 2018), který na rozsáhlé datové bázi dosáhl přesnosti cca $90 \%$. Následně byla provedena klasifikace tweetů z dvouměsíční datové báze.

$Z$ počtu tweetů byly odvozeny vhodné sekundární proměnné (hustoty, podíly, transformované a standardizované hodnoty) a podobně byly variantně zpracovány i nezávisle proměnné (obyvatelstvo, príijem, časový interval mezi spoji, POI, stanice, možnosti přestupů). Výsledky byly analyzovány pomocí EDA, ESDA, modelů OLS a GWR.

Při volbě sousedství se ukázalo, že nelze použít implicitní optimalizace prostorových vah, která vybírala všech 32 jednotek, a na základě logické úvahy byl vybrán model k-sousedů, po krokové optimalizaci bylo dosaženo $\mathrm{k}=12$. 
Při vývoji modelů se prokázalo jako užitečné sledovat standardizovaná rezidua modelu. Jak již bylo uvedeno, měla by být $v$ absolutní hodnotě menší než 2,5. Na obr. 10 jsou vykreslena rezidua modelu G5dens, kde část Retiro přesahuje hodnotu 3 a Salamanca 2.8, což není akceptovatelné. Upravený model G6dens již má chyby akceptovatelně vysoké (obr. 11).

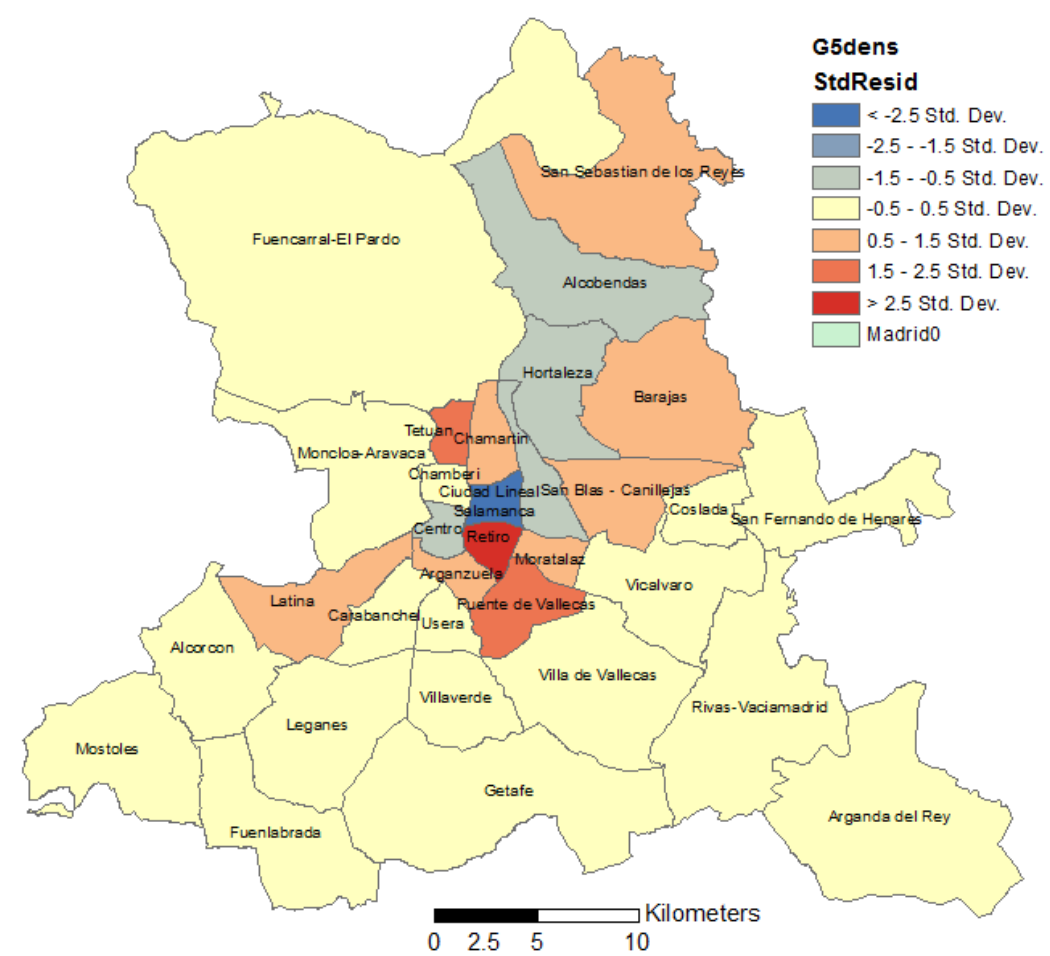

Obr. 10 Standardizovaná rezidua modelu G5dens

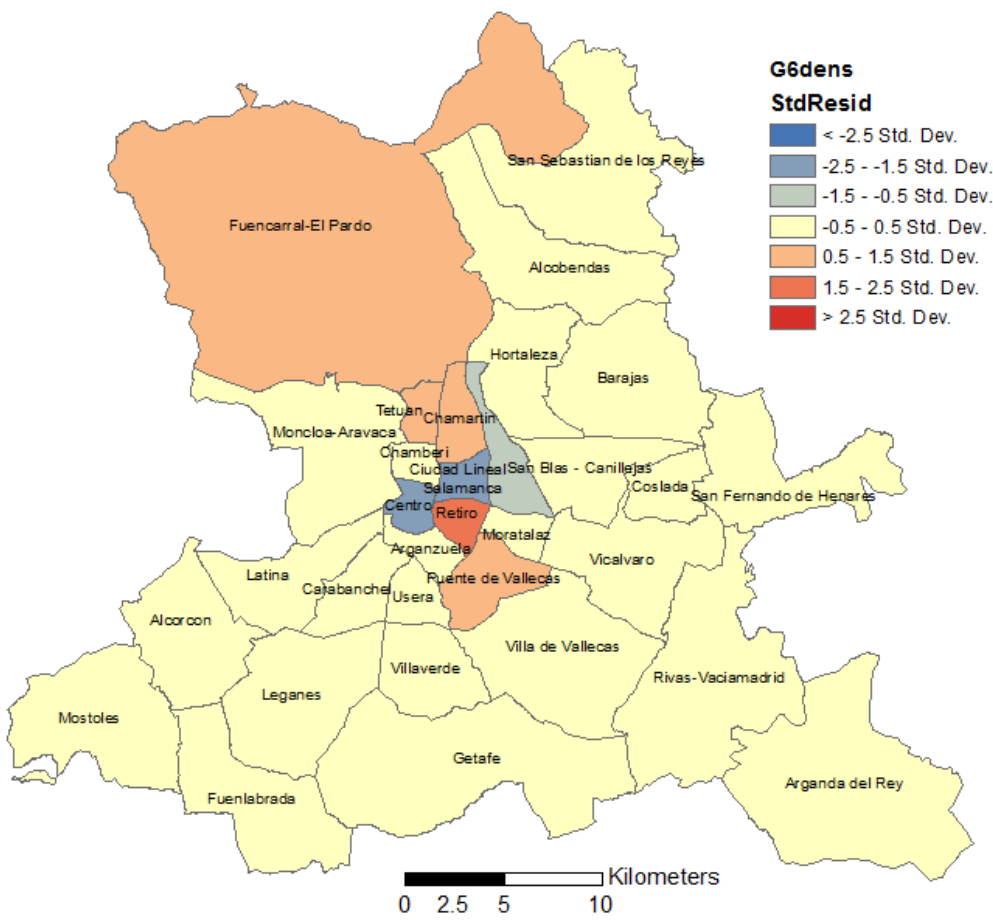

Obr. 11 Standardizovaná rezidua modelu G6dens

Jeden z výsledných modelů GWR sledoval jako závisle proměnnou hustotu stěžujících si uživatelů v závislosti na hustotě obyvatel, jejich př́ijmu a hustotě POI. Lokální regresní koeficienty pro hustotu obyvatel a pro příjem jsou uvedeny na následujících 2 obrázcích. Je zřejmé, že hustota obyvatel (obr. 12) zvyšuje hustotu stižností na sociální síti, tento vliv je však nejvýraznější v SV části Madridu, zatímco v centru je minimální až záporný. To je dáno skutečností, že v centru není hustota rezidenčních obyvatel významným 
faktorem, ale prosazuje se mnohem více vliv hustoty POI, který odráží počty turistů, tvořících významnou část cestujících. Naproti tomu př́jem obyvatel (obr. 13) zesiluje stižnosti osob na dopravu zejména $v$ jižní části území.

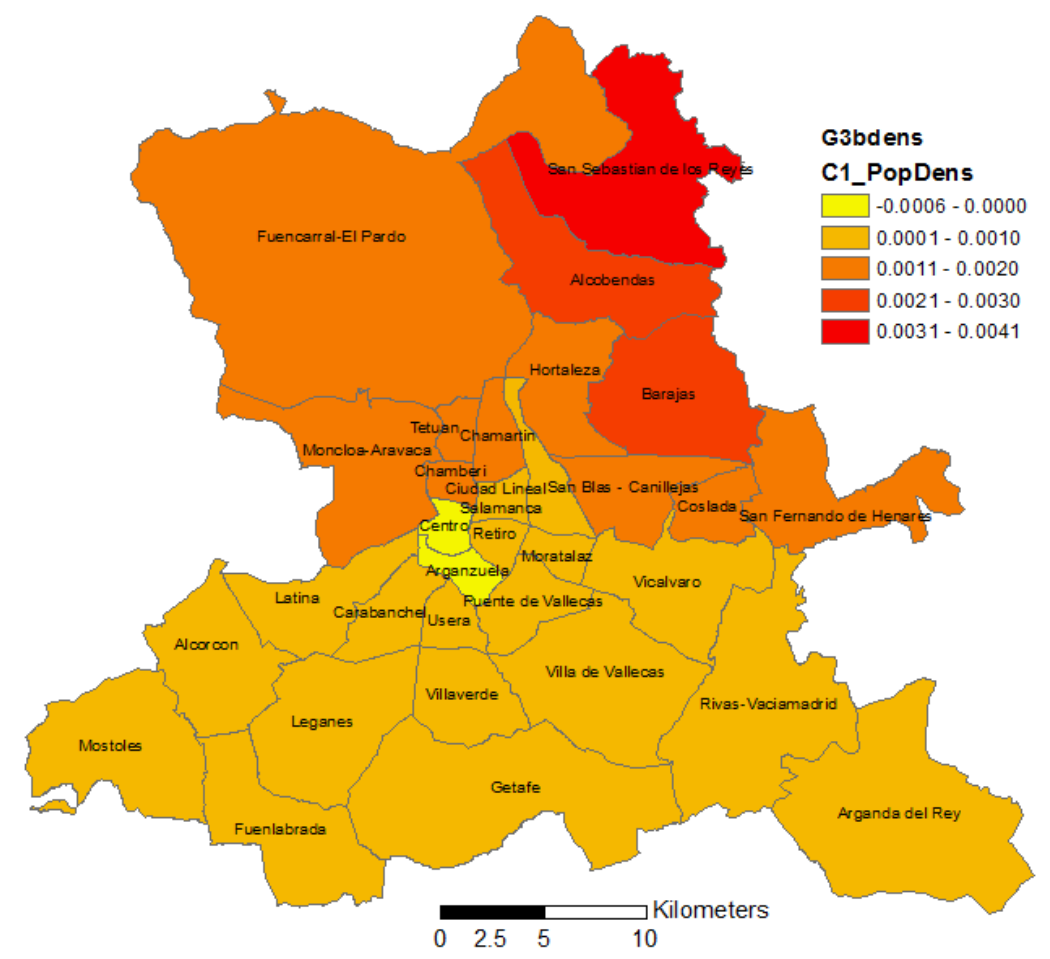

Obr. 12 Lokální koeficienty pro hustotu obyvatel v modelu G3bdens

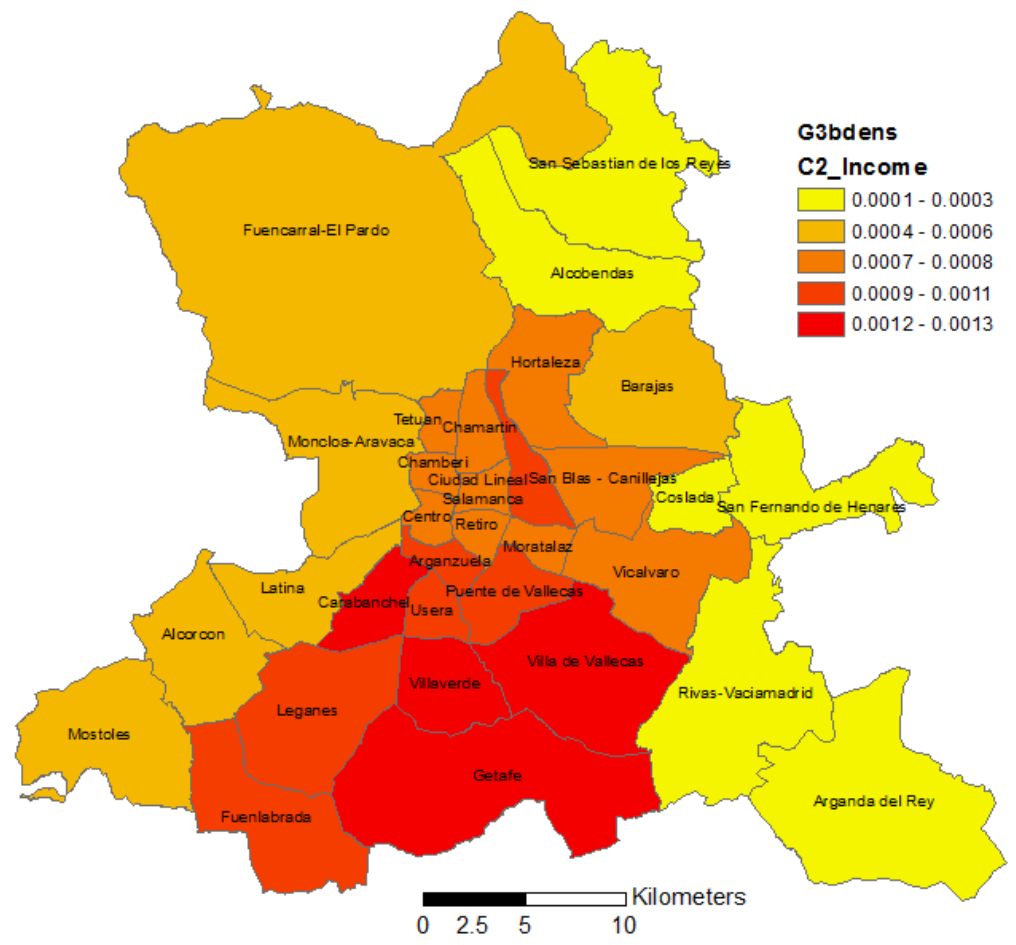

Obr. 13 Lokální koeficienty pro př́ijem obyvatel v modelu G3bdens

\section{ZÁVĚR}

Cílem příspěvku bylo zejména poukázat na doporučené postupy a některé problémy při prostorovém regresním modelování, s využitím dvou případových studií - míry nezaměstnanosti v Česku a distribuce tweetů k dopravě v Madridu. 
Doporučený postup pro prostorové regresní modelování:

- Zvážit typ modelování (účel)

- Zvážit, jaké proměnné vybrat do regresního vztahu a v jaké formě (odlehlé hodnoty, transformace, standardizace, sekundární proměnné).

- Použít EDA a ESDA pro průzkum dat, kontrolu vztahů a studium odlehlých hodnot

- Vytvořit OLS model jako benchmark

- Zvážit typ sousedství a jeho nastavení (nepoužívat slepě optimalizace AIC)

- Pozor na velikost standardizovaných reziduí

- Vytvořit ideálně jak autoregresní tak lokální regresní model.

- Mapovat regresní koeficienty v GWR a provést jejich interpretaci

V každém případě je potřebné hodně přemýšlet o použitých datech, o výsledcích a kriticky zvažovat jejich interpretaci.

\section{LITERATURA}

1. Akinwande, M. O., Dikko, H. G., \& Samson, A. (2015). Variance Inflation Factor: As a Condition for the Inclusion of Suppressor Variable(s) in Regression Analysis. Open Journal of Statistics, 05(07), 754-767. https://doi.org/10.4236/ojs.2015.57075

2. Anselin L. (1988). Spatial Econometrics: Methods and Models. London: Kluwer. $284 \mathrm{s.}$

3. Anselin, L. (2002). Under the Hood: Issues in the Specification and Interpretation of Spatial Regression Models. Agricultural Economics 27(3). s. 247-267.

4. Brunsdon C, Fotheringham AS, Charlton M (1996) Geographically weighted regression: A method for exploring spatial nonstationarity. Geogr Anal 28(4). s. 281-298.

5. Devlin, J., Chang, M.-W., Lee, K., \& Toutanova, K. (2018). BERT: Pre-training of Deep Bidirectional Transformers for Language Understanding. Dostupné z http://arxiv.org/abs/1810.04805

6. Elhorst, J.P. (2010). Spatial Panel Data Models. In Fischer, M.M. and Getis, A., Eds., Handbook of Applied Spatial Analysis: Software Tools, Methods and Applications, Springer Berlin Heidelberg, Berlin, 377-407. http://dx.doi.org/10.1007/978-3-642-03647-7_19

7. Haining, R. (2003). Spatial Data Analysis Theory and Practice. Cambridge University Press, Cambridge. 432 s.

8. Horák, J. (2019): Prostorové analýzy dat. Ostrava: VŠB-TU Ostrava. 181 s. ISBN 978-80-248-4368-1. Dostupné na http://homel.vsb.cz/ hor10/Vyuka/PAD/SkriptaPAD2019.pdf

9. Horák, J., Orlíková, L. (2019): Spatial Component in Regression Modelling of Unemployment in Czechia. In Proceedings of SMSIS (Strategic Management and its Support by Information Systems) 2019, Ostrava, 21-22.5.2019. $15 \mathrm{~s}$.

10. Ivan (2014): Kvantitativní metody v geografii. VŠB-TU Ostrava, 2014. $110 \mathrm{~s}$.

11. LeSage J. P. (1998). Spatial Econometrics. 273 s.

12. Openshaw, S. (1984). The modifiable areal unit problem. CATMOG (38). ISBN 0306-6142

13. Spurná P. (2006): Současné trendy v kvantitativní analýze geografických dat se zaměřením na využité metody geograficky vážené regrese DP Katedra sociální geografie a regionálního rozvoje PřF UK, Praha, $150 \mathrm{~s}$.

14. Rabušic, L., Soukup, P., Mareš, P. (2019): Statistická analýza sociálněvědních dat (prostřednictvím SPSS). 2. přeprac.vyd. Brno: Masarykova univerzita. ISBN 978-80-210-9248-8.

15. Smith M.J., Goodchild M.F., Longley P.A.: Geospatial Analysis. http://www.spatialanalysisonline.com 2018.

16. Vaus, D. (2002): Analysing Social Science Data. London: Sage. 


\section{PŘíLOHA 1 - ZKRÁCENÝ VÝPIS EXPLORATORNÍ REGRESNÍ MODELOVÁNÍ V ARCGIS PRO DATA TWITTER Z MADRIDU}

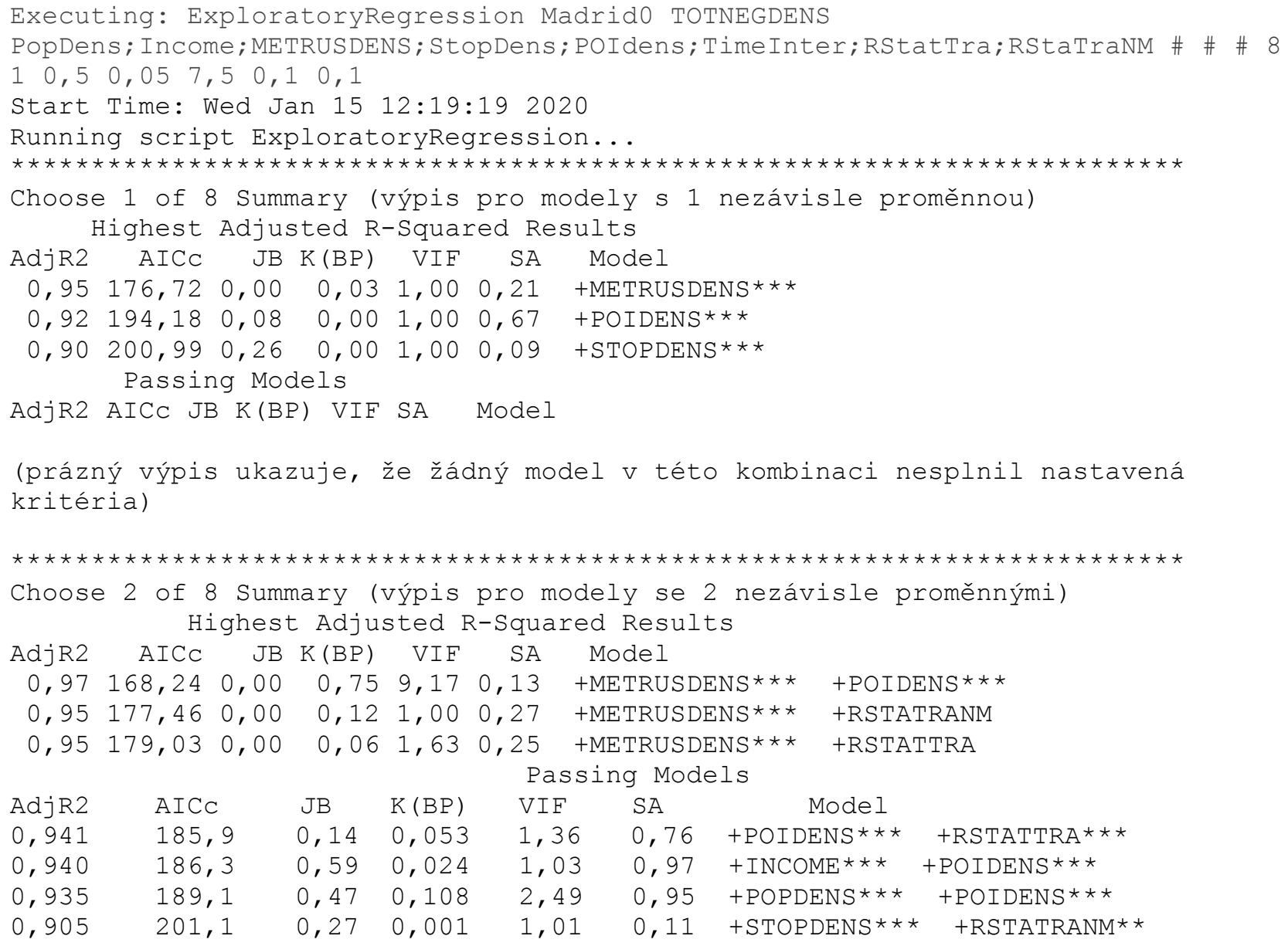

Atd.

Na konci je shrnutí modelování:

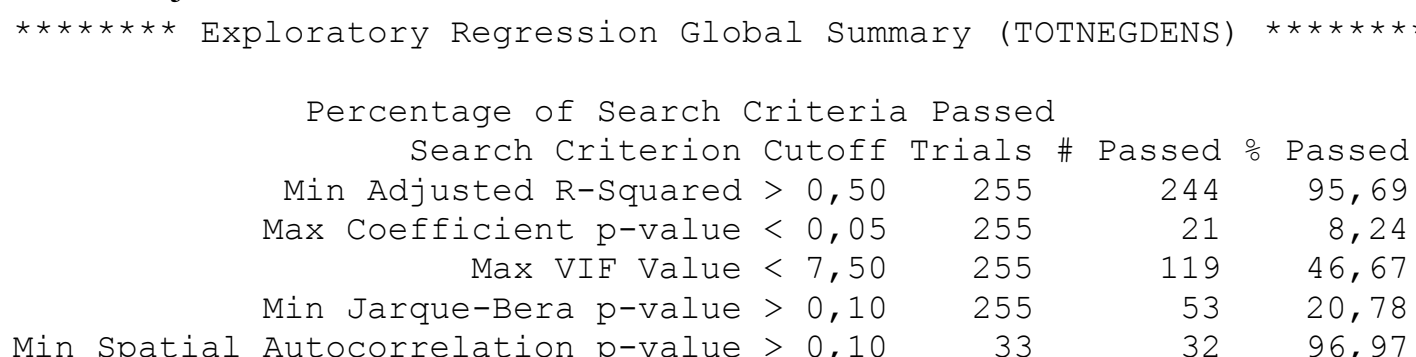

Summary of Variable Significance

$\begin{array}{lrrr}\text { Variable } & \% \text { Significant } & \text { Negative } & \text { Positive } \\ \text { METRUSDENS } & 100,00 & 0,00 & 100,00 \\ \text { POIDENS } & 100,00 & 0,00 & 100,00 \\ \text { STOPDENS } & 37,50 & 32,81 & 67,19 \\ \text { RSTATTRA } & 25,00 & 25,00 & 75,00 \\ \text { POPDENS } & 22,66 & 33,59 & 66,41 \\ \text { INCOME } & 20,31 & 13,28 & 86,72 \\ \text { RSTATRANM } & 11,72 & 21,09 & 78,91 \\ \text { TIMEINTER } & 1,56 & 38,28 & 61,72\end{array}$




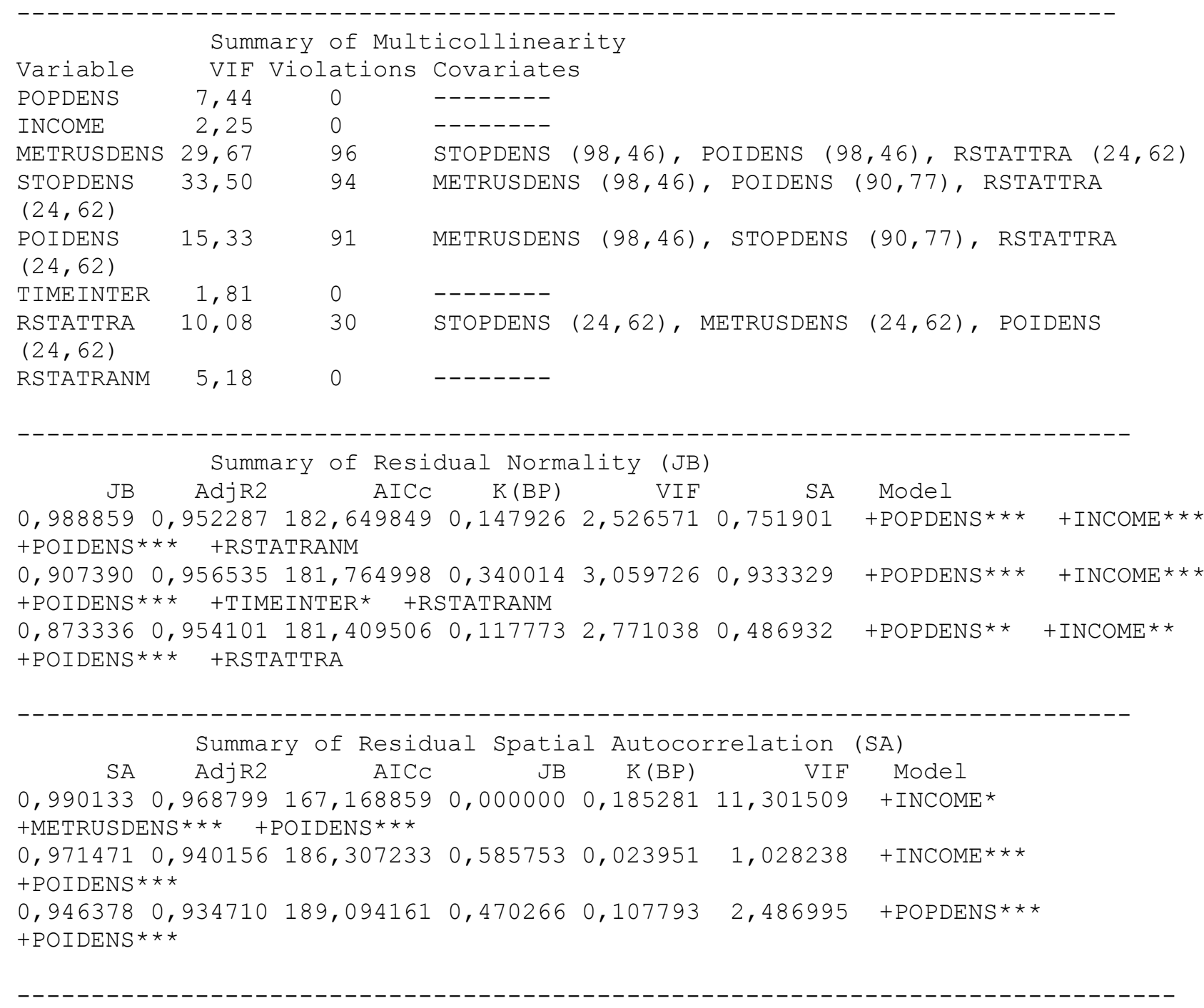

Table Abbreviations

AdjR2 Adjusted R-Squared

AICC Akaike's Information Criterion

JB Jarque-Bera p-value

K(BP) Koenker (BP) Statistic p-value

VIF Max Variance Inflation Factor

SA Global Moran's I p-value

Model Variable sign (+/-)

Model Variable significance $(*=0,10 ; * \star=0,05 ; \star \star \star=0,01)$ 


\section{PŘíLOHA 2 VÝSLEDEK RELATIVNĚ DOBRÉHO MODELU OLS V PROSTŘEDÍ GEODA}

REGRESSION

\begin{tabular}{|c|c|c|c|c|}
\hline $\begin{array}{l}\text { SUMMARY OF OUTPUT: OR } \\
\text { Data set }\end{array}$ & $\begin{array}{l}\text { INARY LEAST } \\
\text { Madrid0 }\end{array}$ & SQUARES ESTIMATION & & \\
\hline Dependent Variable : & TOTNEGDENS & Number of Observations & & 32 \\
\hline Mean dependent var & 9.39425 & Number of Variables & : & 4 \\
\hline S.D. dependent var & 16.2049 & Degrees of Freedom & : & 28 \\
\hline R-squared & \multicolumn{3}{|c|}{$0.956510 \quad$ F-statistic } & $: \quad 205.276$ \\
\hline Adjusted R-squared & 0.951850 & Prob (F-statistic) & \multicolumn{2}{|c|}{$: 3.67558 e-019$} \\
\hline Sum squared residual: & 365.452 & Log likelihood & : & -84.3724 \\
\hline Sigma-square : & 13.0519 & Akaike info criterion & : & 176.745 \\
\hline S.E. of regression & 3.61274 & Schwarz criterion & : & 182.608 \\
\hline Sigma-square ML & 11.4204 & & & \\
\hline S.E of regression ML: & 3.3794 & & & \\
\hline
\end{tabular}

\begin{tabular}{|c|c|c|c|c|}
\hline Variable & Coefficient & Std.Error & t-statistic & Probability \\
\hline CONSTANT & -9.69656 & 2.30528 & -4.20624 & 0.00024 \\
\hline PopDens & 0.000596339 & 0.000210264 & 2.83615 & 0.00839 \\
\hline Income & 0.00039049 & 0.000116043 & 3.36505 & 0.00223 \\
\hline POIdens & 0.0596027 & 0.00462762 & 12.8798 & 0.00000 \\
\hline
\end{tabular}

REGRESSION DIAGNOSTICS

MULTICOLLINEARITY CONDITION NUMBER 8.977722

TEST ON NORMALITY OF ERRORS

$\begin{array}{lrrl}\text { TEST } & \text { DF } & \text { VALUE } & \text { PROB } \\ \text { Jarque-Bera } & 2 & 0.6393 & 0.72640\end{array}$

DIAGNOSTICS FOR HETEROSKEDASTICITY

RANDOM COEFFICIENTS

$\begin{array}{lrrl}\text { TEST } & \text { DF } & \text { VALUE } & \text { PROB } \\ \text { Breusch-Pagan test } & 3 & 4.8797 & 0.18082 \\ \text { Koenker-Bassett test } & 3 & 3.8588 & 0.27712\end{array}$

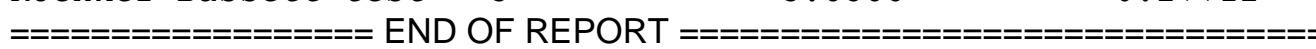




\section{PŘÍLOHA 3 VÝSLEDEK RELATIVNĚ DOBRÉHO MODELU OLS V PROSTŘEDÍ ARCGIS}

Povšimněte si nevýznamnosti proměnných StopDens a Timelnter.

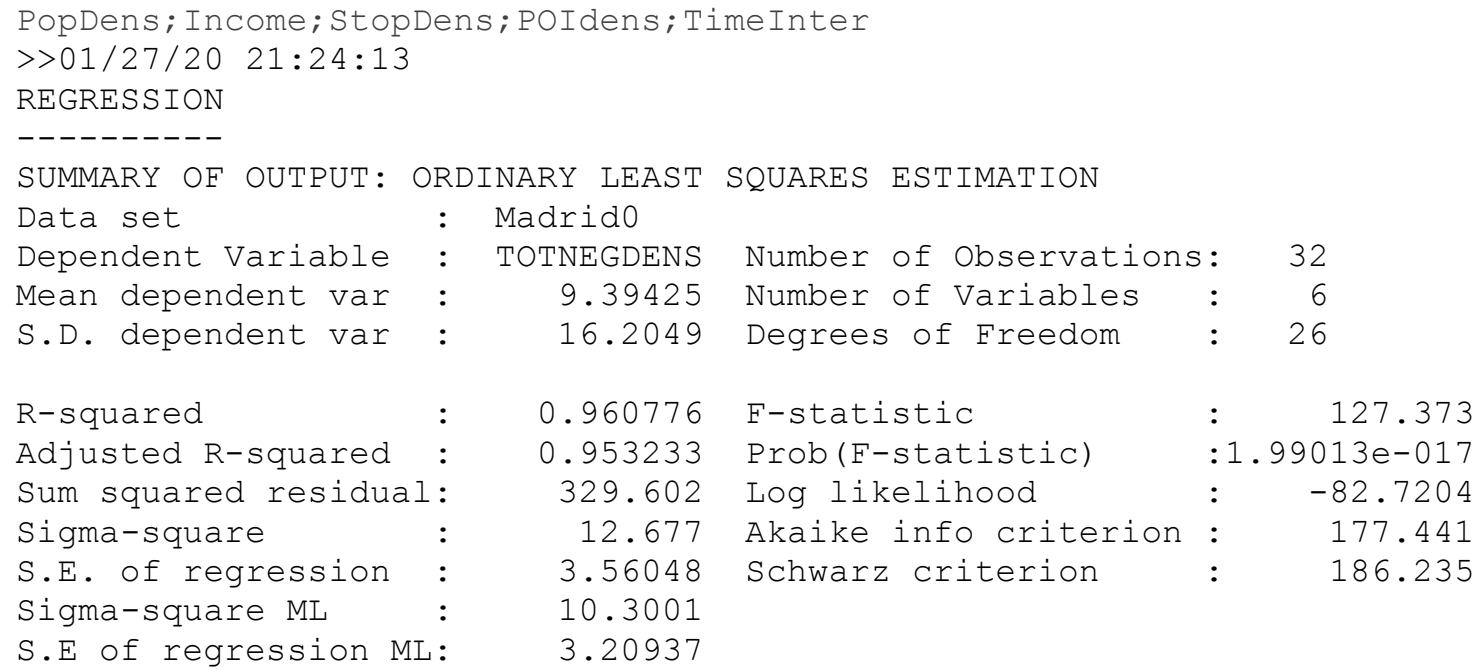

\begin{tabular}{|c|c|c|c|c|}
\hline Variable & Coefficient & Std.Error & t-statistic & Probability \\
\hline --------- & ------------ & ---------- & ------------ & --ー--ー--ー-- \\
\hline CONSTANT & -16.7216 & 6.04847 & -2.7646 & 0.01034 \\
\hline PopDens & 0.000670545 & 0.00034947 & 1.91875 & 0.06606 \\
\hline POIdens & 0.0565493 & 0.00933369 & 6.05862 & 0.00000 \\
\hline Income & 0.000420885 & 0.000145265 & 2.89735 & 0.00754 \\
\hline StopDens & 1.06254 & 3.50805 & 0.302885 & 0.76439 \\
\hline TimeInter & 1.20074 & 0.797291 & 1.50602 & 0.14412 \\
\hline
\end{tabular}

REGRESSION DIAGNOSTICS

MULTICOLLINEARITY CONDITION NUMBER 27.024993

TEST ON NORMALITY OF ERRORS

$\begin{array}{lrrl}\text { TEST } & \text { DF } & \text { VALUE } & \text { PROB } \\ \text { Jarque-Bera } & 2 & 0.4312 & 0.80606\end{array}$

DIAGNOSTICS FOR HETEROSKEDASTICITY

RANDOM COEFFICIENTS

$\begin{array}{lrrl}\text { TEST } & \text { DF } & \text { VALUE } & \text { PROB } \\ \text { Breusch-Pagan test } & 5 & 8.8169 & 0.11659 \\ \text { Koenker-Bassett test } & 5 & 6.9205 & 0.22662\end{array}$

Koenker-Bassett test $5 \quad 6.9205 \quad 0.22662$ 